\title{
The gut microbiota and its metabolites in mice are affected by high heat treatment of Bactrian camel milk
}

\author{
Jing He, ${ }^{1}$ Ruxin Sun, ${ }^{1}$ Xiaoli Hao, ${ }^{1}$ Altantsatsral Battulga, ${ }^{1}$ Namuunaa Juramt, ${ }^{2} \mathrm{Li}$ Yi, ${ }^{1}$ Liang Ming, ${ }^{1}$ \\ and Ji Rimutu ${ }^{1,3 *}$ \\ ${ }^{1}$ Key Laboratory of Dairy Biotechnology and Engineering, Ministry of Education, College of Food Science and Engineering, \\ Inner Mongolia Agricultural University, Hohhot, Inner Mongolia, 010010 China \\ ${ }^{2}$ School of Life Sciences, Peking University, Beijing, 100871 China \\ ${ }^{3}$ Camel Research Institute of Inner Mongolia, Alashan, Inner Mongolia, 750330 China
}

\section{ABSTRACT}

Heat treatment is the most common method used to make milk safe; however, it leads to changes in the organoleptic and nutritional properties of milk. This study aimed to investigate the effects of different heat treatments on nutrients and microbiota of camel milk. The results showed that the nutrient composition of camel milk could be influenced by heat treatment. Ultra-high-temperature treatment of samples significantly reduced levels of camel milk proteins, vitamin $\mathrm{C}$, and lactose, but did not significantly alter the amino acids content. Analysis of $16 \mathrm{~S}$ rRNA amplicon sequences demonstrated that the composition of the intestinal microbiota of mice fed different heat-treated camel milks changed, as did the production of short-chain fatty acids as determined by gas chromatography-mass spectrometry. High temperature/short time treatment had similar effects to UHT treatment on microbial diversity of camel milk; however, the low temperature/ long time treatment had different effects. In addition, higher-temperature treatments changed the abundance of key bacteria at the genus level. These results demonstrated that different heat treatments not only resulted in some nutrient loss, but also changed the proliferation of some probiotic genera. Our results could provide the basis for the potential industrial application of camel milk processing technologies.

Key words: heat treatment, camel milk, nutrient, short-chain fatty acid, microbiota

Received April 4, 2020.

Accepted June 29, 2020.

*Corresponding author: yeluotuo1999@vip.163.com

\section{INTRODUCTION}

Milk is rich in macronutrients, such as proteins, lipids, sugar, vitamins, minerals, and enzymes. Especially, milk is an important source of high-quality protein in the human diet and the most important source of nutrition in infancy. The richness in nutrients of raw milk means that it could harbor pathogens and putrefying microorganisms, making it a threat to human health. Hence, the processing of milk, such as by homogenization and heat treatment, ensures microbial safety and extends shelf life (Claeys et al., 2013). However, the heat treatment of milk not only ensures milk safety, but can also change the primary sensory and nutritional properties of raw milk (Melini et al., 2017). For example, heat treatment can cause irreversible damage, including lactose degradation, protein denaturation, and inactivation of functional components (Felfoul et al., 2016).

In arid and semi-arid regions, inhabitants gain an important part of their nutrition from camel milk. In terms of essential nutrients, camel milk is very similar to cow milk (Elhadi et al., 2015; Nongonierma et al., 2017). However, their relative compositions and protein fractions differ. $\beta$-Casein is the main casein fraction in camel milk. Camel whey is rich in immunoglobulins, lactoferrin, serum albumin, $\alpha$-LA, and lysozyme; however, it has no $\beta$-LG (Khalesi et al., 2017). It also contains higher levels of PUFA and antimicrobial components than other ruminant milk (He et al., 2019). In addition, camel milk has certain medicinal properties and is used to treat different human diseases in some countries (Sawaya et al., 1984; Mihic et al., 2016; Mati et al., 2017).

To ensure camel milk safety and extend shelf life, heat treatment is a key technology. In recent years, a few studies have investigated the changes in contents and functional differences in camel milk samples after different heat treatments. Recent studies showed that 
camel whey proteins were affected by treatment at $80^{\circ} \mathrm{C}$ for $1 \mathrm{~h}$; however, the casein fractions remained intact (Laleye et al., 2008; Lorenzen et al., 2011; Felfoul et al., 2017). Furthermore, camel milk whey showed better thermal stability than bovine or buffalo whey (Farah and Atkins, 1992). Another study found that some nutrients were lost, which affected milk quality, after heat treatment at $100^{\circ} \mathrm{C}$ for 30 min (Elagamy, 2000). Moreover, the functional features of the intestinal microbiota were altered by changes in the nutrients of camel milk (Shao and Wang, 2018). However, little information is available on the changes in gut microbiota and their metabolites following UHT treatment of camel milk. Consequently, in the present study, we aimed to determine the effects of camel milk that had undergone different heat treatments on fecal short-chain fatty acids (SCFA) and changes in gut microbiota of mice. Our results could provide useful information for the dairy industry.

\section{MATERIALS AND METHODS}

\section{Treatment of Camel Milk}

Twenty fresh samples of camel milk were obtained from Bayannur (Inner Mongolia, China). All samples were mixed and stored on ice in sterile containers during transportation to the laboratory. The untreated samples were used as control (raw control milk, RCM), and other samples were treated using different heat processing methods. Heat treatment conditions were as follows: $65^{\circ} \mathrm{C}$ for $30 \mathrm{~min}$ (low temperature/long time; LTLT), $85^{\circ} \mathrm{C}$ for $15 \mathrm{~s} \mathrm{(HTST),} \mathrm{and} 135^{\circ} \mathrm{C}$ for $5 \mathrm{~s}$ (UHT). Whole milk samples were stored at $-20^{\circ} \mathrm{C}$ in a refrigerator.

\section{Animal Experiments}

A total of 24 C57BL/6J male mice (6-8 wk old) were provided by Weitonglihua Experimental Animal Tech Co. (Beijing, China). The mice were reared at $22 \pm$ $2^{\circ} \mathrm{C}$ with a 12-h light/dark cycle and fed a standard chow diet during experimental period. After acclimatization for $1 \mathrm{wk}$, the mice were divided randomly into 4 groups ( $\mathrm{n}=6$ per group): RCM, LTLT, HTST, and UHT groups. All mice received $10 \mathrm{~mL}$ of camel milk/ $\mathrm{kg}$ of BW daily for 4 wk via intraperitoneal injection. On d 28, the colon and fecal contents of all animals were collected.

This study was approved by the Review Committee for the Use of Human or Animal Subjects of the Food Science and Engineering College of Inner Mongolia Ag- ricultural University (Hohhot, China). All procedures were conducted according to the National Institutes of Health Guidelines for the Care and Use of Laboratory Animals (Publication No.85-23, revised 1985).

\section{Determination of Nutrients in Heat-Treated Camel Milk}

The composition of different heat-treated camel milks, including protein, fat, lactose contents, ash, and vitamin $\mathrm{C}$, were determined according to international standard methods (Zhang et al., 2005). Total amino acids were detected using a previously established method (He et al., 2019). The determination of the main nutrients was performed in triplicate.

\section{Determination of SCFA Contents}

Concentrations of SCFA in fecal samples were determined using GC-MS analysis. Sample quantification was obtained by means of acetic, propionic, butyric, and valeric acid standard curves.

\section{S rRNA Sequencing}

Twenty-four cecal samples were collected for $16 \mathrm{~S}$ rRNA gene amplicon sequencing. The $16 \mathrm{~S}$ rRNA gene (V3-V4 variable region) was amplified using primers 338F/806R. Specifically, a QIAamp Fast DNA stool Mini Kit (Qiagen, Valencia, CA) was used to extract total DNA from mouse feces, according to the manufacturer's instructions. A Phusion High-Fidelity PCR Master Mix Kit (catalog no. M0541, New England Biolabs, Ipswich, MA) was used to carry out all the PCR reactions. After purification and quantification of the PCR products, they were subjected to DNA sequencing using the Illumina MiSeq (Illumina Inc., San Diego, CA) platform, according to the manufacturer's recommendations, which generated 250-bp paired-end reads. Using QILME version 1.9.1, the sequences were further demultiplexed and analyzed (Zhang et al., 2005). We used the SILVA 16S rRNA reference database to classify taxonomic abundance (https://www.arb-silva.de). Operational taxonomic unit (OTU) clustering was then performed at 97\% sequence identity (Edgar, 2010).

\section{Statistical Analysis}

All data were expressed as the mean \pm standard error of the mean (SEM). The Kruskal-Wallis test with Dunn's multiple comparison test analysis was used to assess significant differences among different groups. 
The $\beta$-diversity was calculated using weighted UniFrac distances with principal coordinate analysis and nonmetric multidimensional scaling, and by hierarchical cluster analysis and Bray-Curtis distance heatmap analysis to illustrate the similarities and differences among the microbial communities. The unweighted pair group method with arithmetic mean (UPGMA) was used to prepare the hierarchical cluster tree. The algorithm linear discriminant analysis of effect size (LEfSe) was used for discovering biomarkers and differences in the taxonomic feature of the 4 groups.

\section{RESULTS}

\section{Nutrient Composition of Camel Milk Under Different Heat Treatments}

The nutrient composition of camel milk in the 4 treatment groups is shown in Table 1. We found that the concentration of certain camel milk nutrients was significantly reduced by heat treatment $(P<0.05)$. We detected significant differences in vitamin $\mathrm{C}$ and lactose contents among the RCM, HTST, and UHT milk samples $(P<0.05)$. Protein content also decreased when camel milk was subjected to HTST and UHT treatment $(P<0.05)$. However, no differences in the amounts of amino acids were observed among the 4 groups.

\section{Taxonomic Annotation of the Gut Microbiota in Camel Milk Under Different Heat Treatments}

In the present study, 24 fecal samples (from the 4 groups) were collected and further evaluated for the effect of heat treatment on the intestinal microbiota from Bactrian camel milk, as assessed by sequencing the $16 \mathrm{~S}$ rRNA V3-V4 region. An average of 54,462 high-quality sequences were acquired for each of the samples, which varied in length from 401 to $405 \mathrm{bp}$ (Supplemental Figure S1A; https://doi.org/10.3168/ jds.2020-18657). Eventually, we obtained 573 OTU at $97 \%$ similarity. The rank-abundance curve showed that for each sample, sufficient sequencing depth had been achieved for the analysis of gut microbiota diversity (Figure S1B).

The taxon-based analysis was performed on the OTU to identify changes in the gut microbiota in all groups. At the phylum level, in the intestinal tract of the mice, the dominant phyla were Firmicutes, Bacteroidetes, Actinobacteria, and Patescibacteria. Firmicutes were dominant in UHT and HTST samples (62.53 and $66.37 \%$, respectively), whereas Bacteroidetes were dominant in the RCM and LTLT samples (70.86 and $58.08 \%$, respectively; Figure 1A). At the family level, Lactobacillaceae (24.00 and 23.00\%), Lachnosiraceae (22.90 and 30.49\%), and Muribaculaceae (21.88 and $21.76 \%$ ) predominated in the gut of UHT and HTST

Table 1. Nutritional variation in different heat treatments of camel milk ${ }^{1}$

\begin{tabular}{|c|c|c|c|c|}
\hline \multirow[b]{2}{*}{ Item } & \multicolumn{4}{|c|}{ Heat treatment ${ }^{2}$} \\
\hline & $\mathrm{RCM}$ & LTLT & HTST & UHT \\
\hline Fat (\%) & $4.05 \pm 0.04^{\mathrm{a}}$ & $3.89 \pm 0.10^{\mathrm{a}}$ & $3.98 \pm 0.10^{\mathrm{a}}$ & $3.87 \pm 0.03^{\mathrm{b}}$ \\
\hline Protein $(\%)$ & $4.15 \pm 0.08^{\mathrm{a}}$ & $3.94 \pm 0.06^{\mathrm{a}}$ & $3.93 \pm 0.03^{\mathrm{b}}$ & $3.91 \pm 0.03^{\mathrm{b}}$ \\
\hline Lactose $(\%)$ & $5.06 \pm 0.12^{\mathrm{a}}$ & $4.85 \pm 0.10^{\mathrm{a}}$ & $4.81 \pm 0.07^{\mathrm{a}}$ & $4.63 \pm 0.07^{\mathrm{b}}$ \\
\hline Ash (\%) & $0.73 \pm 0.01^{\mathrm{a}}$ & $0.73 \pm 0.01^{\mathrm{a}}$ & $0.72 \pm 0.01^{\mathrm{a}}$ & $0.72 \pm 0.01^{\mathrm{a}}$ \\
\hline Vitamin C (mg/100 g) & $30.54 \pm 0.90^{\mathrm{a}}$ & $27.17 \pm 0.65^{\mathrm{a}}$ & $26.99 \pm 0.40^{\mathrm{a}}$ & $25.70 \pm 0.47^{\mathrm{b}}$ \\
\hline Aspartic acid (g/100 g) & $0.26 \pm 0.02^{\mathrm{a}}$ & $0.27 \pm 0.01^{\mathrm{a}}$ & $0.27 \pm 0.02^{\mathrm{a}}$ & $0.24 \pm 0.03^{\mathrm{a}}$ \\
\hline Threonine $(\mathrm{g} / 100 \mathrm{~g})$ & $0.19 \pm 0.01^{\mathrm{a}}$ & $0.20 \pm 0.01^{\mathrm{a}}$ & $0.19 \pm 0.02^{\mathrm{a}}$ & $0.17 \pm 0.02^{\mathrm{a}}$ \\
\hline Serine $(\mathrm{g} / 100 \mathrm{~g})$ & $0.20 \pm 0.01^{\mathrm{a}}$ & $0.21 \pm 0.01^{\mathrm{a}}$ & $0.21 \pm 0.02^{\mathrm{a}}$ & $0.18 \pm 0.02^{\mathrm{a}}$ \\
\hline Glutamic acid (g/100 g) & $0.82 \pm 0.06^{\mathrm{a}}$ & $0.87 \pm 0.04^{\mathrm{a}}$ & $0.87 \pm 0.09^{\mathrm{a}}$ & $0.78 \pm 0.10^{\mathrm{a}}$ \\
\hline Glycine (g/100 g) & $0.05 \pm 0.01^{\mathrm{a}}$ & $0.05 \pm 0.01^{\mathrm{a}}$ & $0.04 \pm 0.02^{\mathrm{a}}$ & $0.04 \pm 0.01^{\mathrm{a}}$ \\
\hline Alanine (g/100 g) & $0.09 \pm 0.01^{\mathrm{a}}$ & $0.09 \pm 0.02^{\mathrm{a}}$ & $0.09 \pm 0.01^{\mathrm{a}}$ & $0.08 \pm 0.01^{\mathrm{a}}$ \\
\hline Valine $(\mathrm{g} / 100 \mathrm{~g})$ & $0.24 \pm 0.02^{\mathrm{a}}$ & $0.25 \pm 0.01^{\mathrm{a}}$ & $0.25 \pm 0.03^{\mathrm{a}}$ & $0.22 \pm 0.03^{\mathrm{a}}$ \\
\hline Methionine $(\mathrm{g} / 100 \mathrm{~g})$ & $0.10 \pm 0.01^{\mathrm{a}}$ & $0.11 \pm 0.01^{\mathrm{a}}$ & $0.11 \pm 0.02^{\mathrm{a}}$ & $0.10 \pm 0.01^{\mathrm{a}}$ \\
\hline Isoleucine $(\mathrm{g} / 100 \mathrm{~g})$ & $0.21 \pm 0.02^{\mathrm{a}}$ & $0.22 \pm 0.01^{\mathrm{a}}$ & $0.23 \pm 0.02^{\mathrm{a}}$ & $0.20 \pm 0.03^{\mathrm{a}}$ \\
\hline Leucine $(\mathrm{g} / 100 \mathrm{~g})$ & $0.37 \pm 0.03^{\mathrm{a}}$ & $0.39 \pm 0.02^{\mathrm{a}}$ & $0.40 \pm 0.04^{\mathrm{a}}$ & $0.35 \pm 0.04^{\mathrm{a}}$ \\
\hline Tyrosine $(\mathrm{g} / 100 \mathrm{~g})$ & $0.15 \pm 0.01^{\mathrm{a}}$ & $0.16 \pm 0.01^{\mathrm{a}}$ & $0.16 \pm 0.02^{\mathrm{a}}$ & $0.14 \pm 0.02^{\mathrm{a}}$ \\
\hline Phenylalanine $(\mathrm{g} / 100 \mathrm{~g})$ & $0.17 \pm 0.02^{\mathrm{a}}$ & $0.18 \pm 0.0^{\mathrm{a}}$ & $0.18 \pm 0.02^{\mathrm{a}}$ & $0.16 \pm 0.02^{\mathrm{a}}$ \\
\hline Histidine (g/100 g) & $0.11 \pm 0.01^{\mathrm{a}}$ & $0.12 \pm 0.01^{\mathrm{a}}$ & $0.12 \pm 0.01^{\mathrm{a}}$ & $0.11 \pm 0.01^{\mathrm{a}}$ \\
\hline Lysine (g/100 g) & $0.29 \pm 0.02^{\mathrm{a}}$ & $0.31 \pm 0.01^{\mathrm{a}}$ & $0.31 \pm 0.03^{\mathrm{a}}$ & $0.28 \pm 0.03^{\mathrm{a}}$ \\
\hline Arginine $(\mathrm{g} / 100 \mathrm{~g})$ & $0.14 \pm 0.02^{\mathrm{a}}$ & $0.15 \pm 0.01^{\mathrm{a}}$ & $0.15 \pm 0.01^{\mathrm{a}}$ & $0.14 \pm 0.02^{\mathrm{a}}$ \\
\hline Proline $(\mathrm{g} / 100 \mathrm{~g})$ & $0.42 \pm 0.02^{\mathrm{a}}$ & $0.42 \pm 0.02^{\mathrm{a}}$ & $0.43 \pm 0.05^{\mathrm{a}}$ & $0.38 \pm 0.05^{\mathrm{a}}$ \\
\hline
\end{tabular}

${ }^{\mathrm{a}, \mathrm{b}}$ Values within a column with different superscript letters indicate significant differences $(P<0.05)$.

${ }^{1}$ Data are shown as the mean \pm SEM.

${ }^{2} \mathrm{RCM}=$ raw camel milk (untreated); LTLT $=$ low temperature/long time $\left(65^{\circ} \mathrm{C}\right.$ for $\left.30 \mathrm{~min}\right) ; \mathrm{HTST}=85^{\circ} \mathrm{C}$ for $15 \mathrm{~s}$; UHT $=135^{\circ} \mathrm{C}$ for $5 \mathrm{~s}$. 

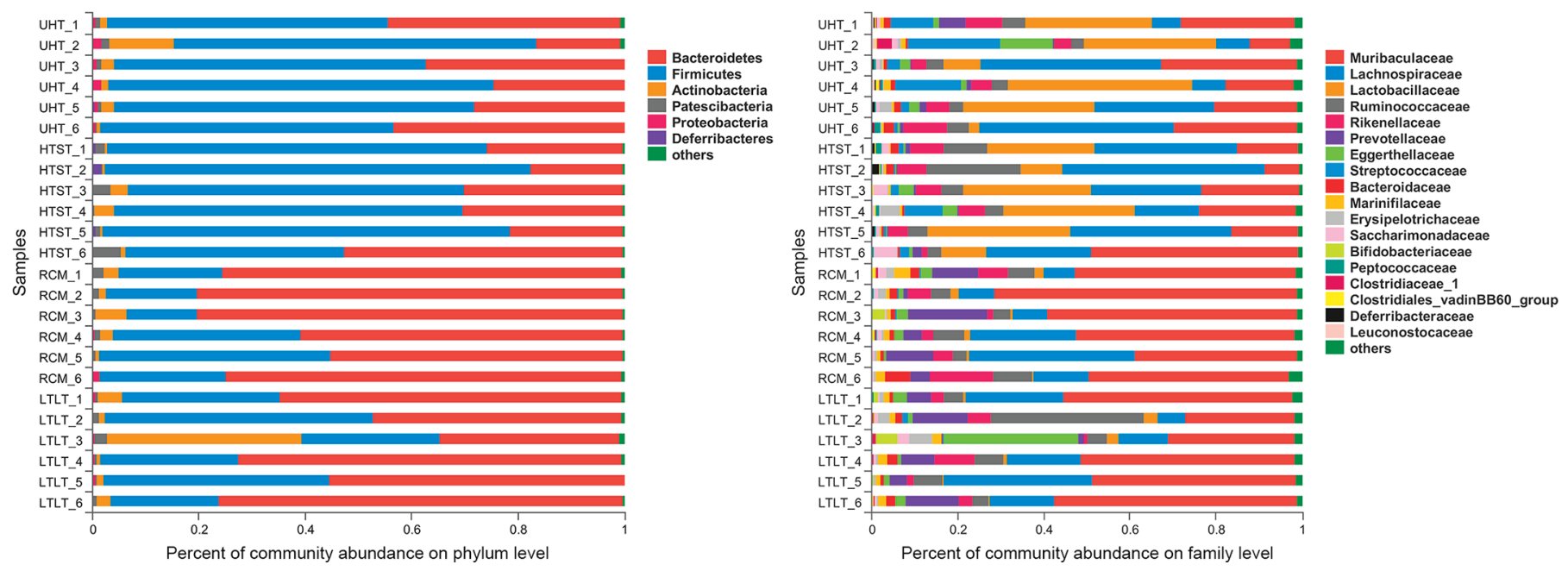

Figure 1. Taxonomic annotation of the gut microbiota at the phyla and family levels. RCM $=$ raw camel milk (untreated); LTLT $=$ low temperature/long time $\left(65^{\circ} \mathrm{C}\right.$ for $\left.30 \mathrm{~min}\right)$; HTST $=85^{\circ} \mathrm{C}$ for $15 \mathrm{~s}$; UHT $=135^{\circ} \mathrm{C}$ for $5 \mathrm{~s}$.

mice, respectively. However, Muribaculaceae (52.37 and 43.56\%), Lachnospiraceae (16.63 and 17.96\%), and Prevotellaceae ( 8.31 and $7.27 \%$ ) were the main communities in the gut of RCM and LTLT mice (Figure 1B). The relative abundances of bacteria from the families Muribaculaceae and Prevotellaceae were significantly lower in the RCM and LTLT samples, whereas those in the Lactobacillaceae and Streptococcaceae decreased significantly in UHT and HTST mice $(P<0.05)$. Hence, the abundance of certain phyla and families differed significantly (Figure 2).

At the genus level, 103 genera were detected in all mice gut microbiota, including norank_f_Muribaculaceae, Lactobacillus, norank_f_Lachnospiraceae, Lactococcus, and Bacteroides. The community heatmap and circus plot showed that the different heat-treated camel milks had altered abundances of specific bacterial taxa at the genus level (Figure 3). Muribaculum, Butyricicoccus, and Papillibacter were the main communities in the gut of the HTST group. Alloprevotella, Muribaculum, Odonbacter, and Bifidobacterium were enriched in the gut of the LTLT group, while Lactobacillus, Lactococcus, and Candidatus_Arthromitus were the key communities in the UHT group (Figure 4). These results indicated that the different heat treatments could inhibit certain bacteria in the mouse gut microbiota.

\section{Diversity of the Gut Microbiota of Camel Milk Under Different Heat Treatments}

We compared the $\alpha$-diversity of the microbiota in all samples using the Chao, ACE, Shannon, and Simpson indices, and found that all 4 indices showed significant differences. For community richness, feeding mice with HTST and UHT camel milk significantly lowered the Sobs (total number of species observed) and Ace indices compared with that of the LTLT group, suggesting that bacterial richness was reduced by hightemperature treatment, especially in the UHT group. However, LTLT treatment of camel milk had only slight and nonsignificant effects on microbial community richness. For community diversity, bacterial diversity was reduced in the HTST and UHT groups compared with the other groups (Figure 5)

The $\beta$-diversity in intestinal microbiomes between all 4 groups are shown in Figure 6. The principal coordinate analysis based on weighted, normalized Unifrac indicated that the gut microbiota had a different distribution of microbes among the groups, and that the bacterial communities of (1) the UHT and HTST samples, and (2) the RCM and LTLT samples were spatially separated. Similar results were found using nonmetric multidimensional scaling analysis. The distances between the RCM and LTLT group samples were shorter than the distance between the UHT and HTST groups, indicating that the RCM and LTLT groups were more similar to each other compared with the other groups. The sample distance heatmap and Bray-Curtis distance cluster analyses also showed differences and similarities between the different samples (Figure 7).

\section{Effects of Heat Treatment on SCFA Production}

The SCFA contents in mice were altered by different heat treatments (Table 2); contents of acetic acid, isobutyric acid, and butyric acid were significantly different among groups $(P<0.05)$. After supplementation of mice with different camel milks, the SCFA contents 


\section{Muribaculaceae}

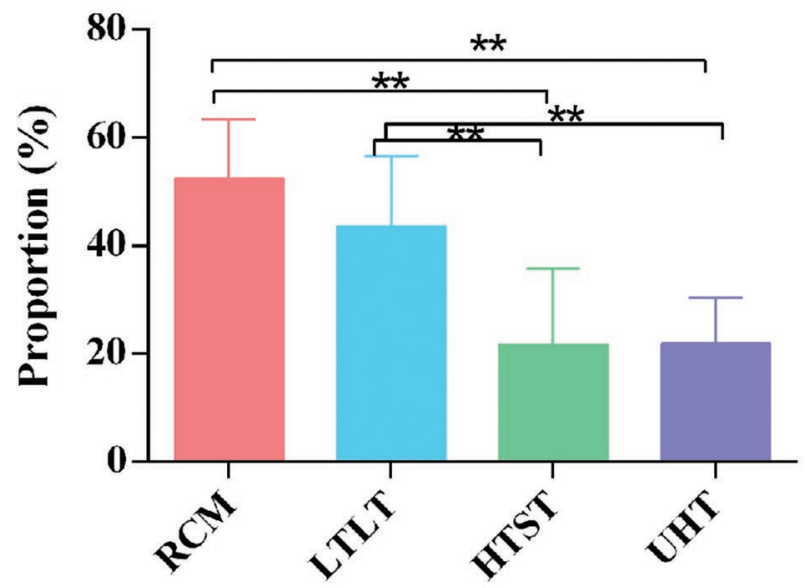

Prevotellaceae

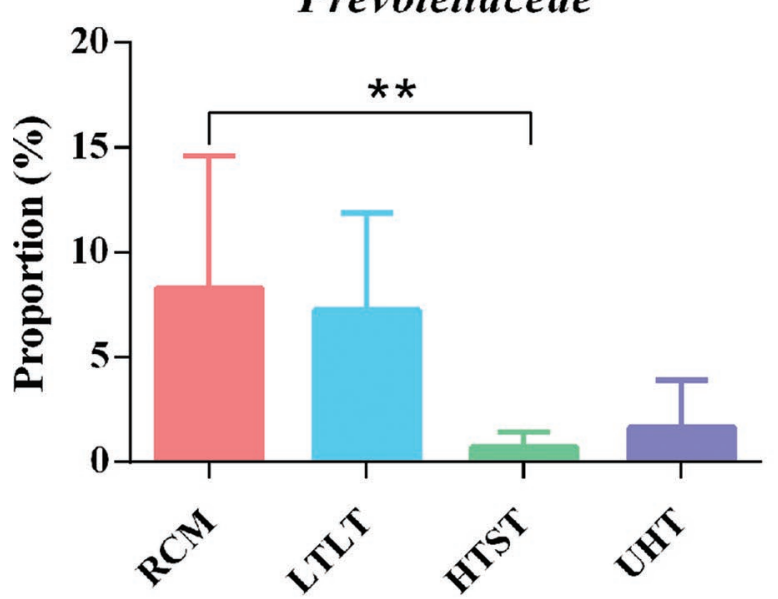

Lactobacillaceae

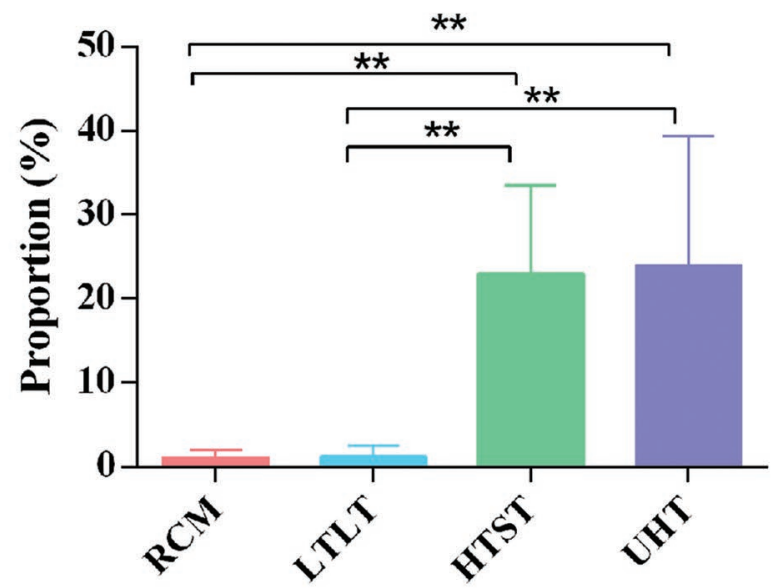

Streptococcaceae

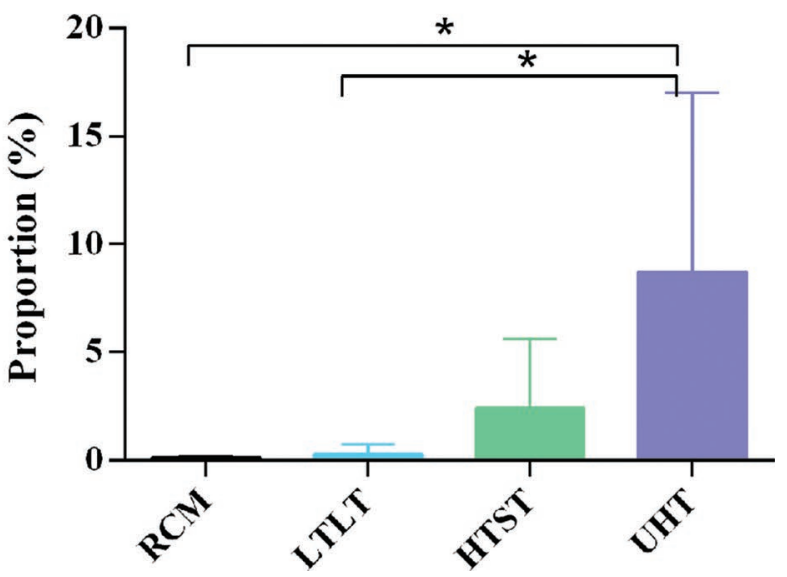

Figure 2. Richness of particular families in the camel gut. RCM $=$ raw camel milk (untreated); LTLT $=$ low temperature/long time $\left(65^{\circ} \mathrm{C}\right.$ for $30 \mathrm{~min}$ ); $\mathrm{HTST}=85^{\circ} \mathrm{C}$ for $15 \mathrm{~s}$; UHT $=135^{\circ} \mathrm{C}$ for $5 \mathrm{~s}$.

were significantly increased in the HTST and UHT groups compared with those in the other groups. There were no significant differences between the HTST and UHT groups. Notably, the concentration of butyric acid in the HTST group was much higher than that in the other groups $(P<0.05)$. However, the HTST and LTLT groups showed no significant differences.

\section{DISCUSSION}

The main aim of heat treatment of milk is to ensure its microbiological safety. However, heat treatment causes changes in the nutritional and organoleptic properties of camel milk. High-temperature heat treatment (e.g., UHT treatment) can induce the formation of lactulose, via isomerization, and of Maillard reaction compounds, formic acid, and lactic acid (Van Boekel, 1998; Law et al., 2010). In this study, we observed that lactose content of camel milk was remarkably lower in the UHT group than in the other groups. Heat treatment decreased the vitamin $\mathrm{C}$ content in camel milk, likely because vitamin $\mathrm{C}$ is heat degradable and may be affected by packaging and storage (MacDonald et al., 2011). Heating, especially UHT and HTST, also decreased the amount of protein, possibly because whey proteins are heat labile and easily undergo heat denaturation (Anema and Li, 2003). Extensive heat treatment also leads to whey proteins becoming associated with casein micelles by interactions with $\kappa$-casein (Anema and Li, 2003; Zhang et al., 2018). Therefore, 


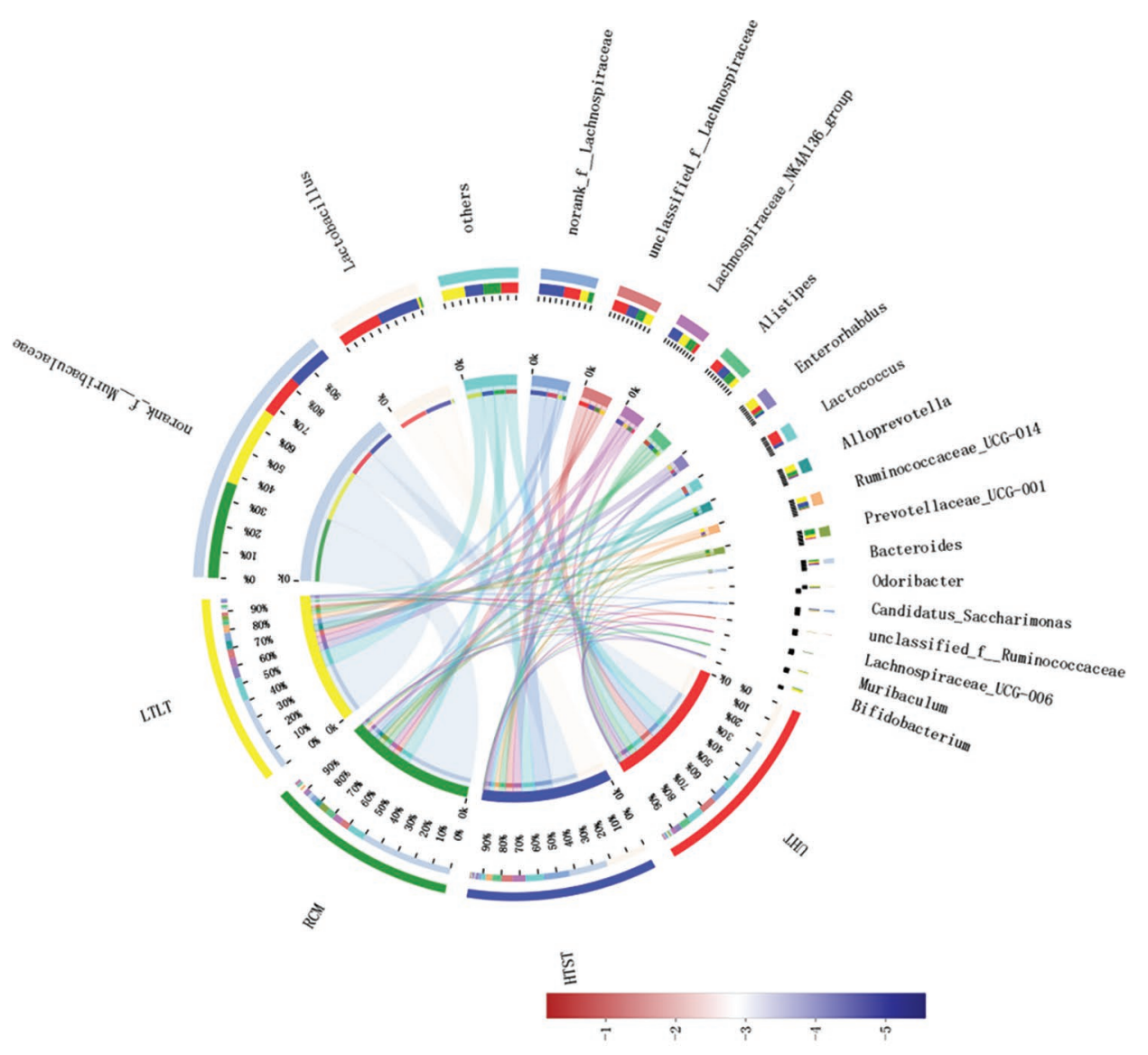

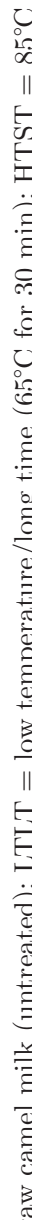
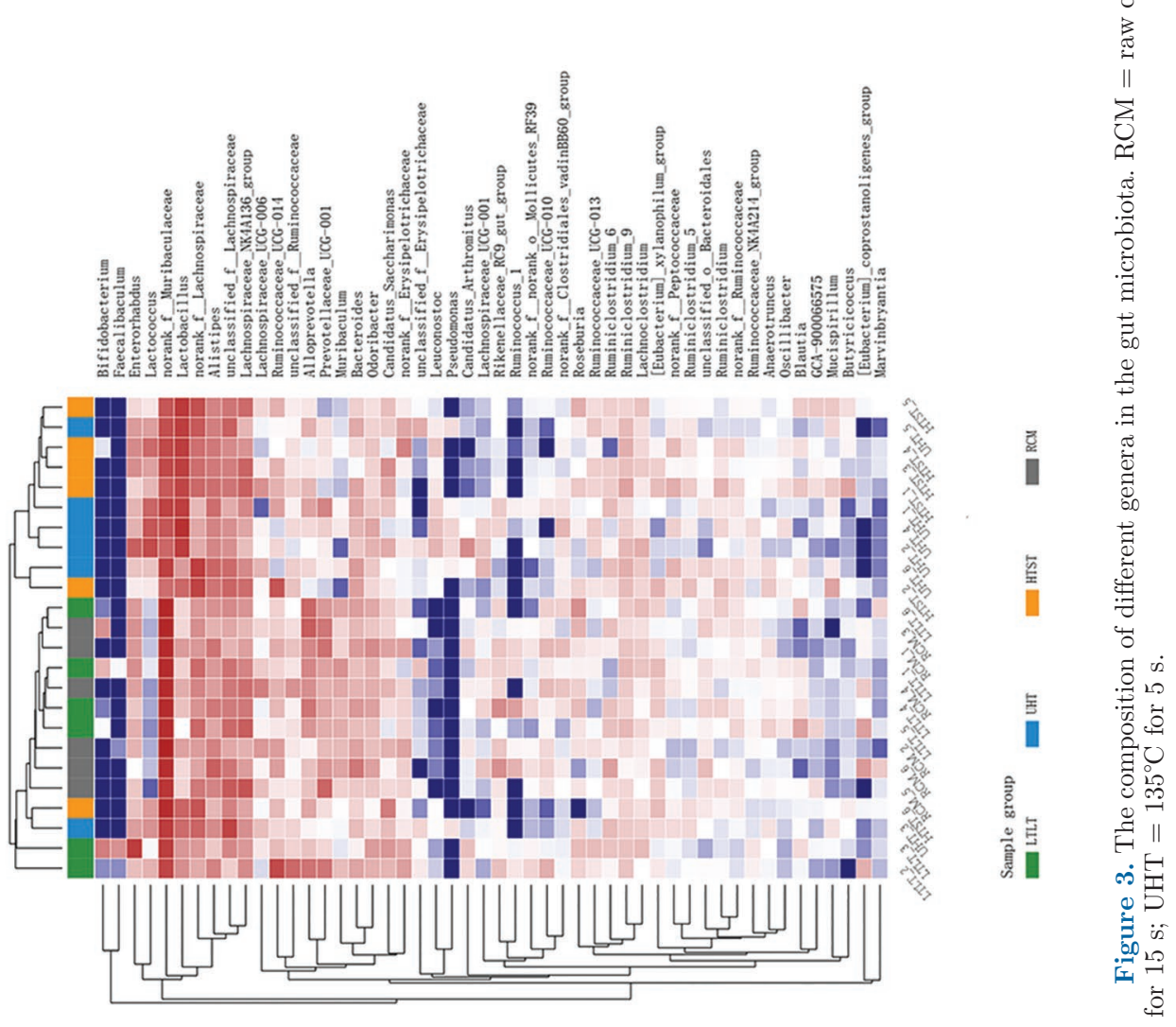


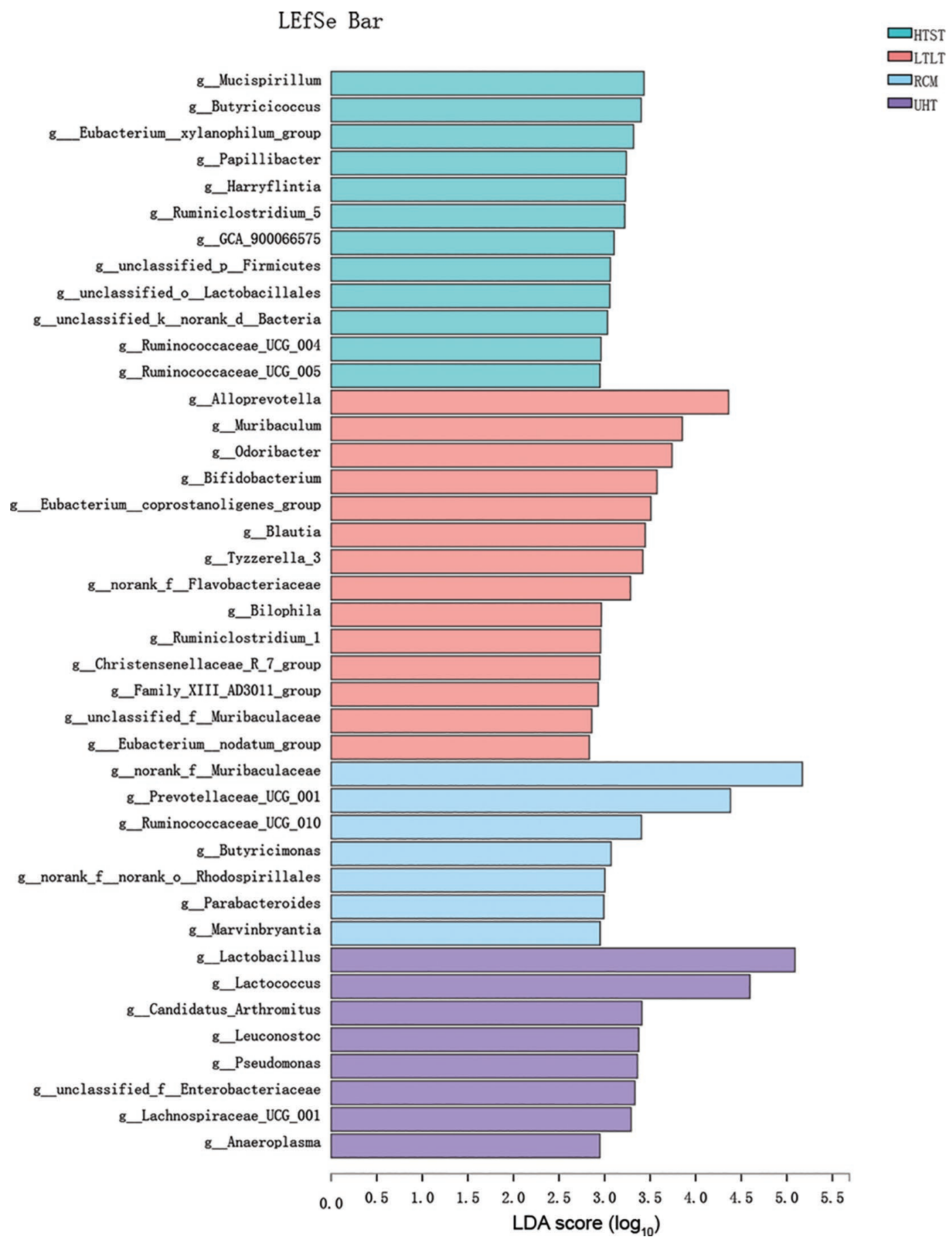

Figure 4. Plot from linear discriminant analysis effect size (LEfSe) analysis indicating enriched bacterial genera ( $g_{-}=$genus; $f_{-}=$family). LDA score $=$ linear discriminant analysis score; $\mathrm{RCM}=$ raw camel milk (untreated); LTLT $=$ low temperature/long time $\left(65^{\circ} \mathrm{C}\right.$ for 30 min); $\mathrm{HTST}=85^{\circ} \mathrm{C}$ for $15 \mathrm{~s}$; UHT $=135^{\circ} \mathrm{C}$ for $5 \mathrm{~s}$.

heat treatment can alter not only the physicochemical properties but also the nutritional functionality of milk (Barbé et al., 2013; Ye et al., 2016). For amino acid contents, similar to previous findings, heat resulted in 1 to $4 \%$ loss of lysine but had little effect on levels of other amino acids (Claeys et al., 2013; Melini et al., 2017).

The characteristics of gut microbes depend on the host's genome, nutrition, and lifestyle (Nicholson et al., 2012). A balanced gut microbiota composition benefits 

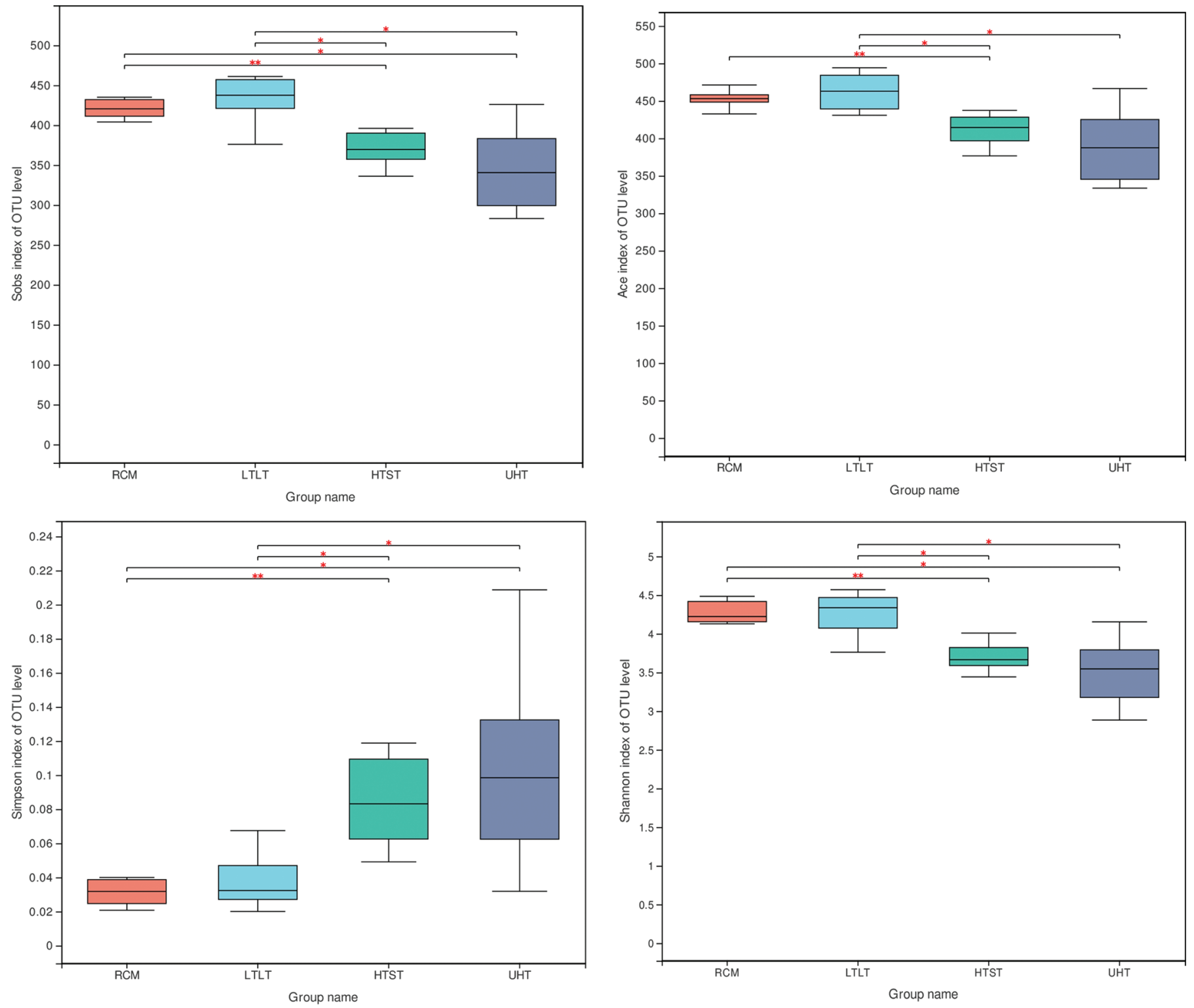

Figure 5. Comparison of the $\alpha$-diversity (in operational taxonomic units, OTU) of gut microbiome among the 4 treatment groups using boxplots. Boxes span interquartile range; midlines indicate median; whiskers indicate minimum and maximum. RCM $=$ raw camel milk (untreated); LTLT $=$ low temperature/long time $\left(65^{\circ} \mathrm{C}\right.$ for $\left.30 \mathrm{~min}\right)$; HTST $=85^{\circ} \mathrm{C}$ for $15 \mathrm{~s}$; UHT $=135^{\circ} \mathrm{C}$ for $5 \mathrm{~s}$. Sobs level $=$ total number of species observed. ${ }^{*} P<0.05 ; * * P<0.01$.

the host, whereas abnormal changes in the gut microbial community are associated with many metabolic disorders. The microbiome is related to the host's diet and metabolism (Krumbeck et al., 2016; Vaiserman et al., 2017). In this study, we observed different effects of heat-treated camel milk on the gut microbiota of mice. The different heat treatments had significantly different effects on the mouse microbiome structure and composition. The $\alpha$-diversity of the mouse microbiota is typically reduced in response to heat-treated camel milk (Shao and Wang, 2018; Wang et al., 2018), which is consistent with the results of the present study. The gut microbiota of mice fed HTST- and UHT-treated milk clustered closer than that of the mice fed untreated milk and LTLT-treated milk. The loss of certain nutrients in milk treated at higher temperatures might have affected the function of the host microbiome.

Consistent with our findings, Bacteroidetes and Firmicutes have been reported as the most abundant phyla in the mouse microbiota (Shao and Wang, 2018; Wang et al., 2018). We found that the relative abundances of bacteria changed after mice ingested different 

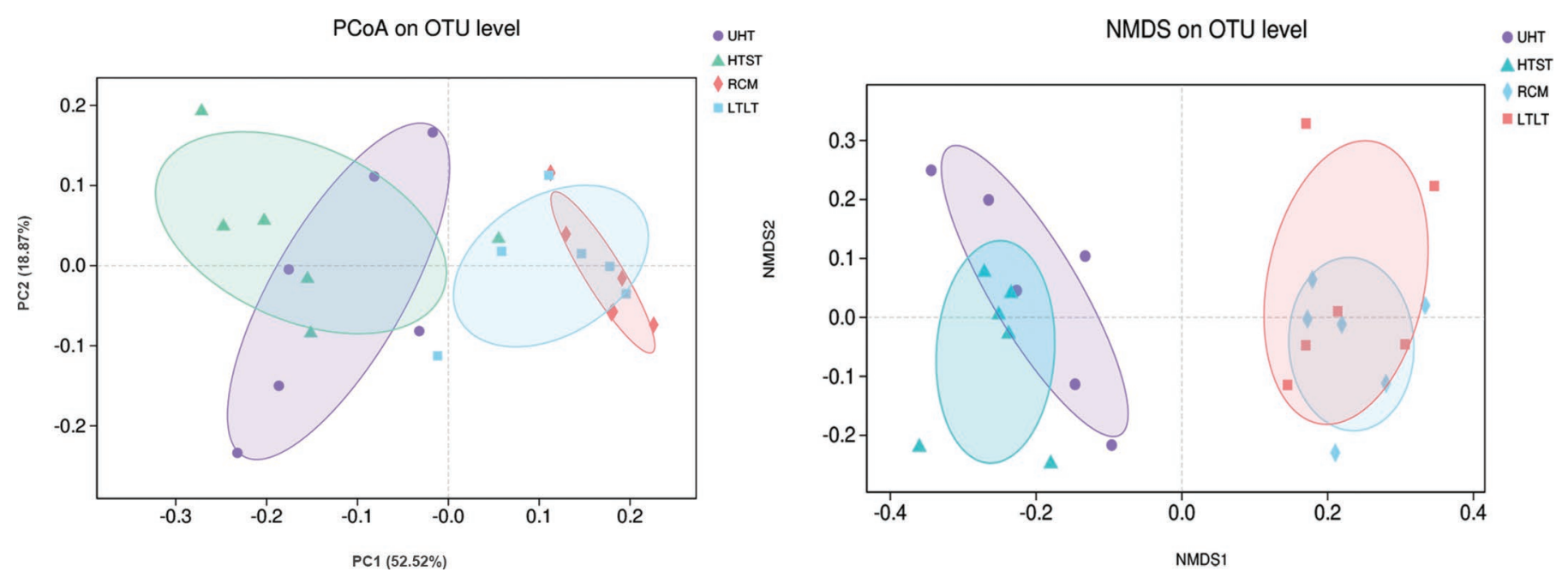

Figure 6. $\beta$-Diversity (in operational taxonomic units, OTU) among the 4 groups based on principal coordinate analysis (PCoA) and nonmetric multidimensional scaling (NMDS). $\mathrm{PC}=$ principal component; RCM = raw camel milk (untreated); LTLT $=$ low temperature/long time $\left(65^{\circ} \mathrm{C}\right.$ for $\left.30 \mathrm{~min}\right)$; $\mathrm{HTST}=85^{\circ} \mathrm{C}$ for $15 \mathrm{~s}$; UHT $=135^{\circ} \mathrm{C}$ for $5 \mathrm{~s}$.

heat-treated camel milks. Feeding UHT milk caused a dramatic change in the mouse gut microbiota by decreasing the population of Firmicutes and increasing that of Bacteroidetes. The Firmicutes proportion is higher in obese individuals, thus the Firmicutes are considered an obesity-related factor (Ley et al., 2006). Thus, high heat treatment of camel milk might reduce the risk of obesity by decreasing Firmicutes levels. At the family level, the Muribaculaceae were drastically decreased in the gut of mice receiving UHT and HTST camel milk compared with mice in the RCM and LTLT groups. Muribaculaceae is a key bacterial marker that is abundant in the microbiota of healthy mice (Lagkouvardos et al., 2019). Dietary changes negatively affect the relative abundance of Muribaculaceae. Moreover, treating camel milk with UHT and HTST can destroy some nutrients, which could induce gut microbiota changes with negative effects.

At the genus level, the abundance of Bifidobacterium was lower in the UHT group than in the LTLT group. This might have resulted from the unchanged content of lactose and protein in the LTLT group, which would be
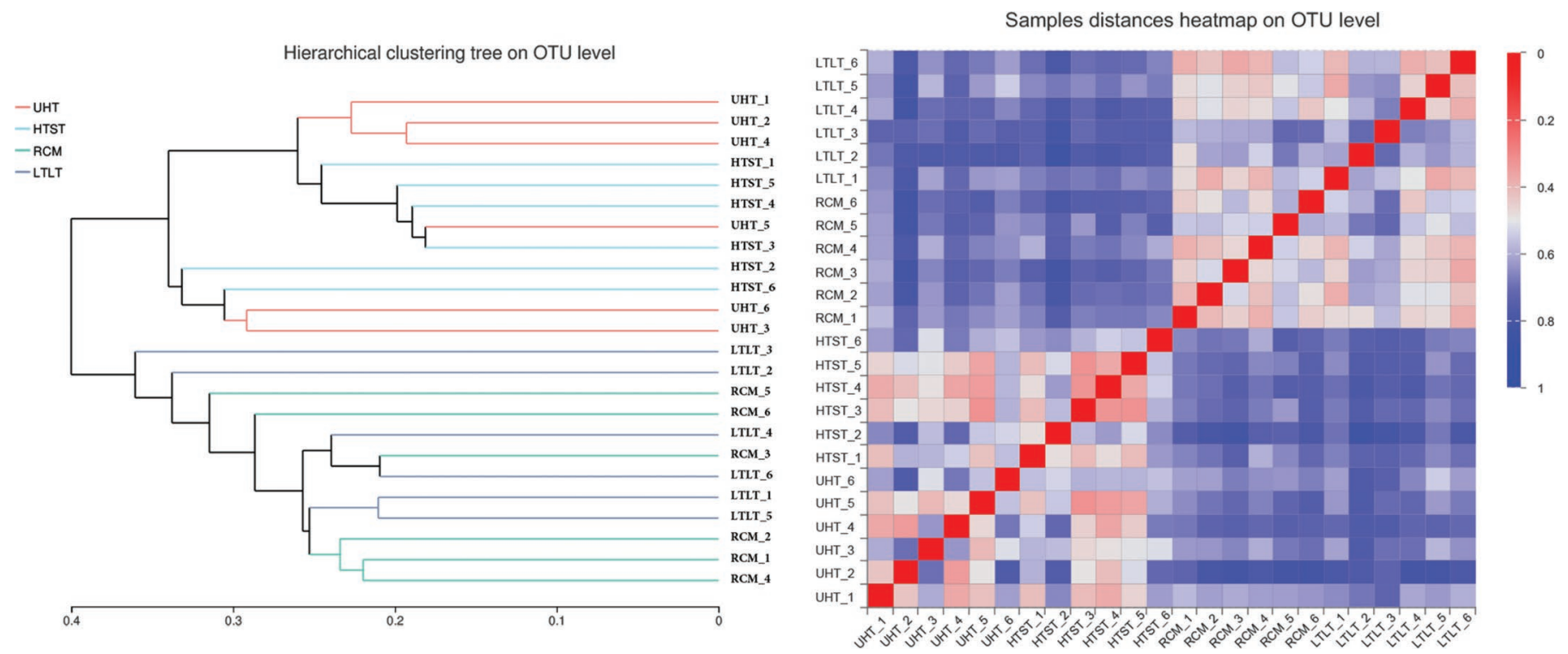

Figure 7. Differences and similarities among 4 groups based on hierarchical clustering and distance on an operational taxonomic unit (OTU) level. RCM = raw camel milk (untreated); LTLT = low temperature/long time $\left(65^{\circ} \mathrm{C}\right.$ for $\left.30 \mathrm{~min}\right) ; \mathrm{HTST}=85^{\circ} \mathrm{C}$ for $15 \mathrm{~s}$; UHT $=135^{\circ} \mathrm{C}$ for $5 \mathrm{~s}$. 
He et al.: HEAT-TREATED CAMEL MILK AND GUT MICROBIOTA

Table 2. Changes in the concentrations $(\mu \mathrm{mol} / \mathrm{g})$ of short-chain fatty acids $(\mathrm{SCFA})^{1}$

\begin{tabular}{|c|c|c|c|c|}
\hline \multirow[b]{2}{*}{ SCFA } & \multicolumn{4}{|c|}{ Heat treatment ${ }^{2}$} \\
\hline & $\mathrm{RCM}$ & LTLT & HTST & UHT \\
\hline Acetic acid & $8.74 \pm 0.68^{\mathrm{a}}$ & $6.54 \pm 1.02^{\mathrm{a}}$ & $27.96 \pm 7.20^{\mathrm{b}}$ & $26.81 \pm 9.85^{\mathrm{b}}$ \\
\hline Propionic acid & $47.39 \pm 28.22^{\mathrm{a}}$ & $27.99 \pm 5.97^{\mathrm{a}}$ & $30.33 \pm 19.97^{\mathrm{a}}$ & $31.52 \pm 13.19^{\mathrm{a}}$ \\
\hline Isobutyric acid & $0.25 \pm 0.10^{\mathrm{ab}}$ & $0.21 \pm 0.07^{\mathrm{a}}$ & $5.71 \pm 1.74^{\mathrm{c}}$ & $3.94 \pm 2.17^{\mathrm{c}}$ \\
\hline Butyric acid & $0.22 \pm 0.07^{\mathrm{a}}$ & $0.24 \pm 0.09^{\mathrm{a}}$ & $5.82 \pm 0.99^{\mathrm{b}}$ & $4.38 \pm 1.11^{\mathrm{a}}$ \\
\hline Isovaleric acid & $0.58 \pm 0.33^{\mathrm{a}}$ & $0.38 \pm 0.08^{\mathrm{a}}$ & $0.39 \pm 0.24^{\mathrm{a}}$ & $0.26 \pm 0.09^{\mathrm{a}}$ \\
\hline Pentanoic acid & $0.24 \pm 0.21^{\mathrm{a}}$ & $0.14 \pm 0.02^{\mathrm{a}}$ & $0.29 \pm 0.11^{\mathrm{a}}$ & $0.23 \pm 0.08^{\mathrm{a}}$ \\
\hline
\end{tabular}

beneficial to the growth of Bifidobacterium. However, in the UHT group, Lactobacillus, a probiotic bacterium that influences host health (Delgado et al., 2020), was dominant. The relative abundance of Lactobacillus was reduced by UHT, in contrast to results of a previous study (Shao and Wang, 2018). Moreover, the lactic acid-producing Lactococcus was a key member of the community after UHT milk intake in this study. Additionally, these results led us to speculate that UHT treatment may not be suitable for camel milk (Felfoul et al., 2017). Previous studies showed that camel milk has natural antimicrobial activity because of the presence of lactoferrin, lysozyme, immunoglobulin, and partially digested or fermented peptides, which can inhibit bacteria in the gut (Beermann and Hartung, 2013; Ahamad et al., 2017; Mati et al., 2017). However, at $65^{\circ} \mathrm{C}$, these antimicrobial compounds mostly retain their activity, whereas at $80^{\circ} \mathrm{C}$, their activity decreases significantly (Felfoul et al., 2017). In this connection, we hypothesize that HTST and UHT heat treatment might reduce antimicrobial components in camel milk.

The present study demonstrated that feeding mice a UHT and HTST milk diet increased the fecal concentration of SCFAs, suggesting that the effect of UHT camel milk on the gut microbiota was to promote the growth of SCFA-producing bacteria. In the intestines, resident bacteria degrade nondigestible food components, including resistant proteins, resistant starches, oligosaccharides, and dietary fibers, and produce SCFA (Morita et al., 1998, Den Besten et al., 2013). Importantly, SCFA modulate host health by affecting glucose homeostasis, maintaining the balance of the epithelial barrier, and regulating energy metabolism (Maslowski et al., 2009; Liu et al., 2019; Tamura et al., 2019). However, recent studies have shown that butyrate is not universally beneficial for intestinal health (Singh et al., 2019; Vancamelbeke et al., 2019). It possible that the degradation of lactose, protein, vitamin $\mathrm{C}$, and some natural antimicrobial components in camel milk changes functional features in the intestines (Shao and Wang, 2018). However, the mechanisms by which these changes in microbial structure and increased concentrations of SCFA, under UHT conditions, affect host health remain unclear.

\section{CONCLUSIONS}

We observed changes in the physicochemical properties of camel milk induced by different heat treatments and these changes were thought to be key factors in altered diversity in gut microbiota of mice receiving the different milks. The change in microbiota induced production of SCFA. Different heat treatments have different effects on the nutritional value of camel milk. In particular, treating camel milk with UHT can destroy some nutrients, which could induce gut microbiota changes with negative effects on the growth of gut probiotics. The LTLT treatment preserved some nutrients and did not induce changes in the diversity or composition of the gut microbiota community. Our results indicate the importance of selecting an appropriate heat treatment for camel milk that will preserve its functional advantages while ensuring its safety.

\section{ACKNOWLEDGMENTS}

Funds for this work were provided by the "First-class Discipline" Construction Fund Project of School of Food Science and Engineering, "Belt and Road" joint Laboratory of China-Mongolia Biopolymer Application and In-depth research and industrial demonstration of camel milk cosmetics. The authors have stated no conflicts of interest.

\section{REFERENCES}

Ahamad, S. R., M. Raish, A. Ahmad, and F. Shakeel. 2017. Potential health benefits and metabolomics of camel milk by GC-MS and ICP-MS. Biol. Trace Elem. Res. 175:322-330. 
Anema, S. G., and Y. Li. 2003. Effect of $\mathrm{pH}$ on the association of denatured whey proteins with casein micelles in heated reconstituted skim milk. J. Agric. Food Chem. 51:1640-1646. https://doi.org/10 $.1021 /$ jf025673a.

Barbé, F., O. Ménard, Y. Le Gouar, C. Buffière, M.-H. Famelart, B. Laroche, S. Le Feunteun, D. Dupont, and D. Rémond. 2013. The heat treatment and the gelation are strong determinants of the kinetics of milk proteins digestion and of the peripheral availability of amino acids. Food Chem. 136:1203-1212. https://doi.org/10 .1016/j.foodchem.2012.09.022.

Beermann, C., and J. Hartung. 2013. Physiological properties of milk ingredients released by fermentation. Food Funct. 4:185-199. https://doi.org/10.1039/C2FO30153A.

Claeys, W. L., S. Cardoen, G. Daube, J. De Block, K. Dewettinck, K. Dierick, L. De Zutter, A. Huyghebaert, H. Imberechts, P. Thiange, Y. Vandenplas, and L. Herman. 2013. Raw or heated cow milk consumption: Review of risks and benefit. Food Control 31:251262. https://doi.org/10.1016/j.foodcont.2012.09.035.

Delgado, S., B. Sánchez, A. Margolles, P. Ruas-Madiedo, and L. Ruiz. 2020. Molecules produced by probiotics and intestinal microorganisms with immunomodulatory activity. Nutrients 12:391. https:// doi.org/10.3390/nu12020391.

den Besten, G., K. Van Eunen, A. K. Groen, K. Venema, D.-J. Reijngoud, and B. M. Bakker. 2013. The role of short-chain fatty acids in the interplay between diet, gut microbiota, and host energy metabolism. J. Lipid Res. 54:2325-2340. https://doi.org/10.1194/ jlr.R036012.

Edgar, R. C. 2010. Search and clustering orders of magnitude faster than BLAST. Bioinformatics 26:2460-2469.

Elagamy, E. I. 2000. Effect of heat treatment on camel milk proteins with respect to antimicrobial factors: A comparison with cows' and buffalo milk proteins. Food Chem. 68:227-232. https://doi.org/10 .1016/S0308-8146(99)00199-5.

Elhadi, Y. A., D. M. Nyariki, and O. V. Wasonga. 2015. Role of camel milk in pastoral livelihoods in Kenya: Contribution to household diet and income. Pastoralism 5:8. https://doi.org/10.1186/s13570 -015-0028-7.

Farah, Z., and D. Atkins. 1992. Heat coagulation of camel milk. J. Dairy Res. 59:229-231. https://doi.org/10.1017/S002202990003048X.

Felfoul, I., E. Beaucher, C. Cauty, H. Attia, F. Gaucheron, and M. Ayadi. 2016. Deposit generation during camel and cow milk heating: microstructure and chemical composition. Food Bioprocess Technol. 9:1268-1275. https://doi.org/10.1007/s11947-016-1714-1.

Felfoul, I., J. Jardin, F. Gaucheron, H. Attia, and M. Ayadi. 2017. Proteomic profiling of camel and cow milk proteins under heat treatment. Food Chem. 216:161-169. https://doi.org/10.1016/j .foodchem.2016.08.007.

He, J., Y. Xiao, K. Orgoldol, L. Ming, L. Yi, and R. Ji. 2019. Effects of geographic region on the composition of Bactrian camel milk in Mongolia. Animals (Basel) 9:890-899. https://doi.org/10.3390/ ani9110890.

Khalesi, M., M. Salami, M. Moslehishad, J. Winterburn, and A. A. Moosavi-Movahedi. 2017. Biomolecular content of camel milk: A traditional superfood towards future healthcare industry. Trends Food Sci. Technol. 62:49-58.

Krumbeck, J. A., M. X. Maldonado-Gomez, A. E. Ramer-Tait, and R. W. Hutkins. 2016. Prebiotics and synbiotics: Dietary strategies for improving gut health. Curr. Opin. Gastroenterol. 32:110. https:// doi.org/10.1097/MOG.0000000000000249.

Lagkouvardos, I., T. R. Lesker, T. C. A. Hitch, E. J. C. Gálvez, N. Smit, K. Neuhaus, J. Wang, J. F. Baines, B. Abt, B. Stecher, J. Overmann, T. Strowig, and T. Clavel. 2019. Sequence and cultivation study of Muribaculaceae reveals novel species, host preference, and functional potential of this yet undescribed family. Microbiome 7:28. https://doi.org/10.1186/s40168-019-0637-2.

Laleye, L. C., B. Jobe, and A. A. H. Wasesa. 2008. Comparative study on heat stability and functionality of camel and bovine milk whey proteins. J. Dairy Sci. 91:4527-4534. https://doi.org/10.3168/jds .2008-1446.
Law, D., J. Conklin, and M. Pimentel. 2010. Lactose intolerance and the role of the lactose breath test. Am. J. Gastroenterol. 105:17261728. https://doi.org/10.1038/ajg.2010.146.

Ley, R. E., P. J. Turnbaugh, S. Klein, and J. I. Gordon. 2006. Human gut microbes associated with obesity. Nature 444:1022-1023. https://doi.org/10.1038/4441022a.

Liu, J., W. Hao, Z. He, E. Kwek, Y. Zhao, H. Zhu, N. Liang, K. Y. Ma, L. Lei, W.-S. He, and Z.-Y. Chen. 2019. Beneficial effects of tea water extracts on the body weight and gut microbiota in C57BL/6J mice fed with a high-fat diet. Food Funct. 10:28472860. https://doi.org/10.1039/C8FO02051E.

Lorenzen, P. C., R. Wernery, B. Johnson, S. Jose, and U. Wernery. 2011. Evaluation of indigenous enzyme activities in raw and pasteurized camel milk. Small Rumin. Res. 97:79-82. https://doi.org/ 10.1016/j.smallrumres.2011.01.014.

Macdonald, L. E., J. Brett, D. Kelton, S. E. Majowicz, K. Snedeker, and J. M. Sargeant. 2011. A systematic review and meta-analysis of the effects of pasteurization on milk vitamins, and evidence for raw milk consumption and other health-related outcomes. J. Food Prot. 74:1814-1832. https://doi.org/10.4315/0362-028X.JFP $-10-269$.

Maslowski, K. M., A. T. Vieira, A. Ng, J. Kranich, F. Sierro, D. Yu, H. C. Schilter, M. S. Rolph, F. Mackay, and D. Artis. 2009. Regulation of inflammatory responses by gut microbiota and chemoattractant receptor GPR43. Nature 461:1282-1286. https://doi.org/ 10.1038/nature08530.

Mati, A., C. Senoussi-Ghezali, S. Si Ahmed Zennia, D. Almi-Sebbane, H. El-Hatmi, and J.-M. Girardet. 2017. Dromedary camel milk proteins, a source of peptides having biological activities-A review. Int. Dairy J. 73:25-37. https://doi.org/10.1016/j.idairyj .2016.12.001.

Melini, F., V. Melini, F. Luziatelli, and M. Ruzzi. 2017. Raw and heat-treated milk: From public health risks to nutritional quality. Beverages 3:54. https://doi.org/10.3390/beverages3040054.

Mihic, T., D. Rainkie, K. J. Wilby, and S. A. Pawluk. 2016. The therapeutic effects of camel milk: A systematic review of animal and human trials. J. Evid. Based Complementary Altern. Med. 21:NP110-NP126. https://doi.org/10.1177/2156587216658846.

Morita, T., S. Kasaoka, A. Oh-hashi, M. Ikai, Y. Numasaki, and S. Kiriyama. 1998. Resistant proteins alter cecal short-chain fatty acid profiles in rats fed high amylose cornstarch. J. Nutr. 128:1156-1164. https://doi.org/10.1093/jn/128.7.1156.

Nicholson, J. K., E. Holmes, J. Kinross, R. Burcelin, G. Gibson, W. Jia, and S. Pettersson. 2012. Host-gut microbiota metabolic interactions. Science 336:1262-1267. https://doi.org/10.1126/science .1223813 .

Nongonierma, A. B., S. Paolella, P. Mudgil, S. Maqsood, and R. J. FitzGerald. 2017. Dipeptidyl peptidase IV (DPP-IV) inhibitory properties of camel milk protein hydrolysates generated with trypsin. J. Funct. Foods 34:49-58. https://doi.org/10.1016/j.jff.2017 .04 .016 .

Sawaya, W. N., J. K. Khalil, A. Al-Shalhat, and H. Al-Mohammad. 1984. Chemical composition and nutritional quality of camel milk. J. Food Sci. 49:744-747. https://doi.org/10.1111/j.1365-2621.1984 .tb13200.x.

Shao, Y., and Z. Wang. 2018. Changes in the nutrients of camels' milk alter the functional features of the intestine microbiota. Food Funct. 9:6484-6494. https://doi.org/10.1039/C8FO00812D.

Singh, V., B. S. Yeoh, R. E. Walker, X. Xiao, P. Saha, R. M. Golonka, J. Cai, A. C. A. Bretin, X. Cheng, Q. Liu, M. D. Flythe, B. Chassaing, G. C. Shearer, A. D. Patterson, A. T. Gewirtz, and M. Vijay-Kumar. 2019. Microbiota fermentation-NLRP3 axis shapes the impact of dietary fibres on intestinal inflammation. Gut 68:1801-1812. https://doi.org/10.1136/gutjnl-2018-316250.

Tamura, K., H. Sasaki, K. Shiga, H. Miyakawa, and S. Shibata. 2019. The timing effects of soy protein intake on mice gut microbiota. Nutrients 12:87. https://doi.org/10.3390/nu12010087.

Vaiserman, A. M., A. K. Koliada, and F. Marotta. 2017. Gut microbiota: A player in aging and a target for anti-aging intervention. Ageing Res. Rev. 35:36-45. https://doi.org/10.1016/j.arr.2017.01.001. 
Van Boekel, M. 1998. Effect of heating on Maillard reactions in milk. Food Chem. 62:403-414. https://doi.org/10.1016/S0308 -8146(98)00075-2.

Vancamelbeke, M., T. Laeremans, W. Vanhove, K. Arnauts, A. S. Ramalho, R. Farré, I. Cleynen, M. Ferrante, and S. Vermeire. 2019. Butyrate does not protect against inflammation-induced loss of epithelial barrier function and cytokine production in primary cell monolayers from patients with ulcerative colitis. J. Crohns Colitis 13:1351-1361. https://doi.org/10.1093/ecco-jcc/jjz064.

Wang, Z., W. Zhang, B. Wang, F. Zhang, and Y. Shao. 2018. Influence of Bactrian camel milk on the gut microbiota. J. Dairy Sci. 101:5758-5769. https://doi.org/10.3168/jds.2017-13860.
Ye, A., J. Cui, D. Dalgleish, and H. Singh. 2016. The formation and breakdown of structured clots from whole milk during gastric digestion. Food Funct. 7:4259-4266. https://doi.org/10.1039/ C6FO00228E

Zhang, H., J. Yao, D. Zhao, H. Liu, J. Li, and M. Guo. 2005. Changes in chemical composition of Alxa Bactrian camel milk during lactation. J. Dairy Sci. 88:3402-3410. https://doi.org/10.3168/jds .S0022-0302(05)73024-1.

Zhang, Y., D. Liu, X. Liu, F. Hang, P. Zhou, J. Zhao, H. Zhang, and W. Chen. 2018. Effect of temperature on casein micelle composition and gelation of bovine milk. Int. Dairy J. 78:20-27. https:// doi.org/10.1016/j.idairyj.2017.10.008. 